\title{
Antioxidant vitamin levels among preschool children with uncomplicated Plasmodium falciparum malaria in Sokoto, Nigeria
}

This article was published in the following Dove Press journal:

Journal of Multidisciplinary Healthcare

10 July 2013

Number of times this article has been viewed

\author{
Festus I Aghedo' \\ Resqua A Shehu \\ Rabiu A Umar ${ }^{2}$ \\ Mohammed $\mathrm{N}$ Jiya $^{3}$ \\ Osaro Erhabor ${ }^{4}$ \\ 'Department of Haematology, \\ Usmanu Danfodiyo University \\ Teaching Hospital, Sokoto, Nigeria; \\ ${ }^{2}$ Department of Biochemistry, \\ Usmanu Danfodiyo University, Sokoto, \\ Nigeria; ${ }^{3}$ Department of Paediatrics, \\ College of Health Sciences, Usmanu \\ Danfodiyo University, Sokoto, Nigeria; \\ ${ }^{4}$ Department of Haematology, Faculty \\ of Medical Laboratory Science, \\ Usmanu Danfodiyo University, \\ Sokoto, Nigeria
}

Correspondence: Osaro Erhabor

Department of Haematology,

Usmanu Danfodiyo University,

Sokoto, Nigeria

Tel +447932363217

Email n_osaro@yahoo.com
Objective: To assess antioxidant vitamin levels among preschool children with plasmodium malarial infection.

Methods: We assessed antioxidant vitamin levels by using a standard procedure in 130 malariaparasitized preschool children. Packed cell volume and parasite density were also evaluated. Forty healthy age- and gender-matched nonparasitized children were included as controls.

Results: Plasmodium falciparum was the causative species in all subjects. The mean malaria parasitemia was $4529.45 \pm 1237.5 / \mu \mathrm{L}$. The mean antioxidant concentrations for vitamins $\mathrm{A}, \mathrm{C}$, and $\mathrm{E}$ among plasmodium-parasitized subjects were $33.15 \pm 1.79 \mu \mathrm{g} / \mathrm{dL}, 0.51 \pm 0.02 \mathrm{mg} / \mathrm{dL}$, and $0.61 \pm 0.02 \mathrm{mg} / \mathrm{dL}$, respectively. The mean concentrations of vitamins A, C, and E among the nonmalaria-parasitized controls were $69.72 \pm 1.71 \mu \mathrm{g} / \mathrm{dL}, 1.25 \pm 0.04 \mathrm{mg} / \mathrm{dL}$, and $1.31 \pm 0.04 \mathrm{mg} / \mathrm{dL}$ respectively. We observed that the mean antioxidant concentrations of vitamins $\mathrm{A}, \mathrm{C}$, and $\mathrm{E}$ were significantly lower among plasmodium-parasitized subjects compared with non-parasitized controls $(P=0.01)$. Malaria parasitemia correlated negatively with antioxidant concentrations and packed cell volume $(r=-0.736$ and $-0.723, P=0.001)$. We observed that the higher the level of parasitemia, the lower the antioxidant concentration.

Conclusion: Our study has shown that the antioxidant levels in plasmodium-parasitized children in the North-West of Nigeria are low and that the more severe the malarial infection, the lower the antioxidant level and the packed cell volume. One key strategic intervention is the provision of early diagnosis and prompt effective treatment. We recommend that malaria-parasitized children, particularly those in the North-West of Nigeria, be placed routinely on antioxidant vitamins to manage the micronutrient deficiencies seen in these children. There is also the need for the promotion of insecticide-treated bed nets, intermittent preventive treatment, and effective case management of malarial illness among children.

Keywords: vitamin A, vitamin C, vitamin E, P. falciparum

\section{Introduction}

Malaria poses an enormous public health burden, and greater than $75 \%$ of the global clinical episodes of malarial infection each year are concentrated in Africa. According to latest estimates from the World Health Organization, in 2009, there were 225 million cases of malaria and an estimated 781,000 deaths worldwide. Most of these deaths occurred among children living in the World Health Organization African Region (mainly sub-Saharan Africa). ${ }^{1}$ Malaria was the eighth highest contributor to the world loss of disability-adjusted life years in 2001, and second in Africa. ${ }^{2,3}$ It is one of the greatest and oldest health challenges affecting $40 \%$ of the world's population. ${ }^{4}$

The clinical and epidemiological disease burden of malaria morbidity and mortality is dependent largely on the complex pathogenesis of this parasite infection. ${ }^{5}$ It is 
characterized by a stable, perennial transmission in all parts of Nigeria, with transmission reaching its peak in the wet seasons. The disease can be contracted at least two times in a year, and $30 \%-40 \%$ of out-patient consultations and pediatric admissions are due to malaria. ${ }^{6,7}$ The mechanism that might affect the pathogenesis and antioxidant status of children with malaria is thought to be the production of excess free radicals, which induces lipid peroxidation and cell damage. In children, micronutrient status has been shown to influence resistance to several infectious diseases, including measles, diarrhea, and respiratory diseases. ${ }^{8-11}$ A randomized trial in Papua New Guinea has shown that periodic vitamin A supplementation could reduce the incidence of febrile episodes and parasitemia due to Plasmodium falciparum. ${ }^{12}$ Vitamin A is essential for normal immune function and has been shown to influence both antibody response and cell-mediated immunity. ${ }^{13}$ Vitamin $\mathrm{C}$ is a negative acute phase reactant. Plasma vitamin $\mathrm{C}$ concentration correlates inversely with white cell count, alpha-1-acid glycoprotein, and interleukin-6, all of which are markers of inflammation. ${ }^{14}$ Vitamin $\mathrm{C}$ can rejuvenate vitamin $\mathrm{E}$, making it an indirect contributor to fighting free-radical damage in membrane lipids. ${ }^{15}$ These free radicals are products of oxidative stress that is aggravated in malarial infection to decrease the antioxidant defense system. One of the implications of oxidative stress is the development of malarial anemia. ${ }^{16}$ It has been reported that antioxidants such as carotenoid and vitamins $\mathrm{C}$ and $\mathrm{E}$ could provide protection against oxidative stress induced by malaria. ${ }^{16-18}$ There is paucity of literature on the antioxidant level in plasmodium-parasitized children in the North-West of Nigeria. The aim of this present study was to investigate the relationship between $P$. falciparum malaria and antioxidant concentration in a hospital-based study involving preschool children with uncomplicated $P$. falciparum malaria in Sokoto State in the North-West geopolitical zone of Nigeria.

\section{Materials and method}

\section{Study site}

The study was conducted in the Sokoto municipality between June 2009 and August 2010. Sokoto State is located in the extreme North-West of Nigeria, near to the confluence of the Sokoto River and the Rima River. With an annual average temperature of $28.3^{\circ} \mathrm{C}\left(82.9^{\circ} \mathrm{F}\right)$, Sokoto is, on the whole, a very hot area. However, maximum daytime temperatures are for most of the year generally under $40^{\circ} \mathrm{C}\left(104.0^{\circ} \mathrm{F}\right)$. The warmest months are February to April, when daytime temperatures can exceed $45^{\circ} \mathrm{C}\left(113.0^{\circ} \mathrm{F}\right)$. The rainy season is from June to October, during which showers are a daily occurrence. There are two

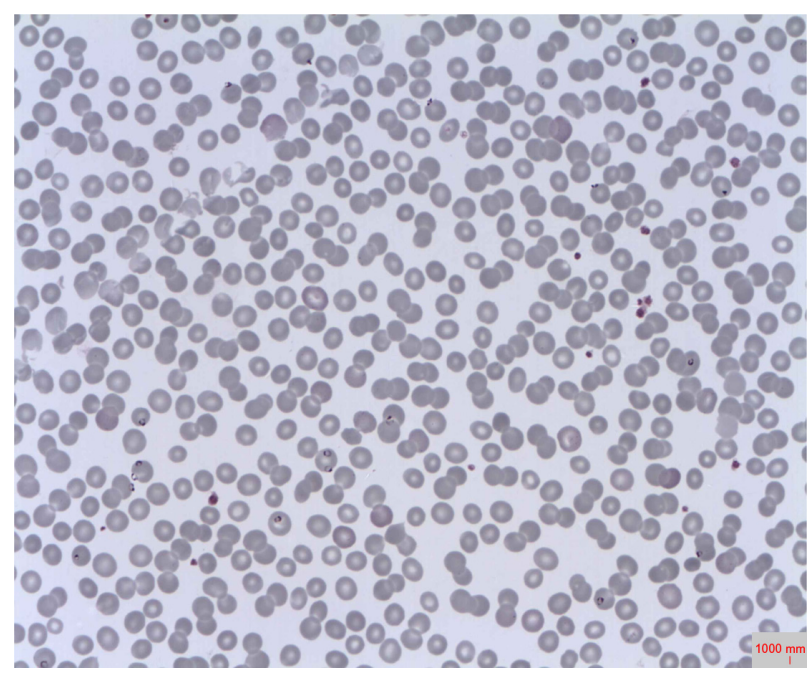

Figure I A Plasmodium falciparum-positive slide.

major seasons: wet and dry, which are distinct and characterized by high and low malarial transmission, respectively. The state has a population of 3.6 million. ${ }^{19}$ In Sokoto, as in other cities in Northern Nigeria, malaria is hyper-endemic ${ }^{20}$ and $P$. falciparum is the predominant species (Figure 1). ${ }^{21}$

\section{Subjects}

The study subjects consisted of 130 children aged 2-60 months old who were recruited at the outpatient clinic of the Department of Paediatrics of Usmanu Danfodiyo University Teaching Hospital, Sokoto. Consenting subjects who presented with signs and symptoms suggestive of simple/ uncomplicated malaria ${ }^{22}$ (fever with axillary temperature $>37.5^{\circ} \mathrm{C}$, headache, vomiting, diarrhea, prostration, pallor, jaundice, respiratory distress, and other clinical signs and symptoms) were recruited into this study. Written informed consent was obtained from the parent/guardian of each child after thoroughly explaining the scope, nature, and objective of the study and offering counseling. Demographic data including age, weight, and height were measured and recorded. Exclusion criteria for subjects included age (less than 2 months or older than 60 months), children with sickle-cell disease, viral hepatitis B, tonsillitis, otitis media, respiratory distress, recent history of convulsion and history of HIV (human immunodeficiency virus)/AIDS (acquired immunodeficiency syndrome) infection. Ethical approval was obtained from the ethical committee of Usmanu Danfodiyo University Teaching Hospital.

\section{Sample collection}

The study population in this case-control study comprised 130 malaria-infected children who attended the pediatric 
clinic of Usmanu Danfodiyo University Teaching Hospital, Sokoto. Forty healthy age- and gender-matched nonparasitized children were included as controls. The number of control participants is adequate for the power of the study. Five milliliters of venous blood was obtained from each participant by venepuncture. Two milliliters of the blood was collected into an EDTA (ethylenediaminetetraacetic acid) bottle for the determination of packed cell volume, confirmation of malaria parasitemia, speciation, and parasite count. Blood smears (thin and thick films) were prepared for all malariapositive subjects and non-parasitized controls. Thick and thin films were stained with Field's stain (for confirmation, speciation, and parasite load determination) and were read for 200 fields. Parasite counts were reported per 500 white blood cells and for counts above 1,000 parasites. Malaria parasitemia was defined by the presence of asexual forms of $P$. falciparum, confirmed by microscopic examination of the peripheral blood. The parasitemia was graded as low $(<500$ parasites $/ \mu \mathrm{L})$, moderate $(3,000$ parasites $/ \mu \mathrm{L})$, and severe $(>10,000$ parasites $/ \mu \mathrm{L})$. Three milliliters of venous blood was collected into a clean plain tube without anticoagulant and allowed to clot at room temperature. The serum was obtained by centrifugation for 10 minutes at $3000 \mathrm{rpm}$. Vitamin A was assayed by the method of Bassey et al, ${ }^{23}$ vitamin $\mathrm{C}$ was assayed by the method of Roe and Kuether, ${ }^{24}$ and Vitamin E was assayed by the method of Neild and Person. ${ }^{25}$ The data obtained from this investigation were subjected to statistical analysis.

\section{Statistical analysis}

Data were entered and analyzed using statistical package SPSS version 9 (SPSS Inc, Chicago, IL, USA). Statistical analyses included descriptive analysis of mean, standard deviation, and chi-square analysis. A $P$-value of $>0.05$ was considered to be statistically significant in all statistical analyses. Correlation was compared using a version of linear regression analysis.

\section{Results}

The plasma antioxidant levels, packed cell volume, and parasite counts of control subjects and malaria-infected children are shown in Table 1. The antioxidant vitamin A, C, and $E$ levels and packed cell volume were lower in malariainfected children when compared with control subjects. $P$. falciparum was the causative species in all the subjects studied. The values of the antioxidant vitamins $A$, $\mathrm{C}$, and $\mathrm{E}(33.15 \pm 1.79 \mu \mathrm{g} / \mathrm{dL}, 0.51 \pm 0.02 \mathrm{mg} / \mathrm{dL}$, and $0.61 \pm 0.02 \mathrm{mg} / \mathrm{dL}$, respectively) and packed cell volume
Table I Plasma antioxidant vitamin levels, packed cell volume and parasite count in malaria-infected children

\begin{tabular}{lcc}
\hline Parameters & $\begin{array}{l}\text { Control } \\
\text { participants } \\
(\mathbf{N}=\mathbf{4 0})\end{array}$ & $\begin{array}{l}\text { Plasmodium } \\
\text { parasitized subjects } \\
\mathbf{( N = 1 3 0 )}\end{array}$ \\
\hline Vitamin A $(\mu \mathrm{g} / \mathrm{dL})$ & $69.72 \pm 1.7 \mathrm{I}$ & $33.15 \pm 1.79$ \\
Vitamin C $(\mathrm{mg} / \mathrm{dL})$ & $1.25 \pm 0.04$ & $0.5 \mathrm{I} \pm 0.02$ \\
Vitamin E $(\mathrm{mg} / \mathrm{dL})$ & $1.31 \pm 0.04$ & $0.61 \pm 0.02$ \\
Packed cell volume $(\%)$ & $38.55 \pm 0.63$ & $34.57 \pm 0.64$ \\
Parasite count $(/ \mu \mathrm{L})$ & Nil & $4529.45 \pm 1237.50$ \\
\hline
\end{tabular}

Notes: Mean +/- SD.

Abbreviations: $\mathrm{N}$, number; SD, standard deviation.

$(34.57 \% \pm 0.64 \%)$ were observed to be significantly lower in malaria-infected children compared with control subjects $(P=0.01)$.

Table 2 shows the antioxidant vitamin levels and intensity of malaria parasitemia. Plasma antioxidants and packed cell volume decreased with increasing malaria severity. Parasitemia was classified as mild $(<500$ parasites $/ \mu \mathrm{L})$, moderate $(<3000$ parasites $/ \mu \mathrm{L})$, and severe $(>10,000 / \mu \mathrm{L})$ infection. Antioxidant vitamins and packed cell volume in subjects with severe malaria were significantly lower than those with mild and moderate malarial infections. We observed a significant negative correlation between the parasite load, the antioxidant vitamin status, and packed cell volume $(r=-0.736$ and $-0.723, P=0.001)$.

Table 3 shows the antioxidant profiles according to the age groups of the plasmodium-parasitized subjects. Children between the ages of 13 and 60 months old had the highest $P$. falciparum load of $3979.0 \pm 1173.4 / \mu \mathrm{L}$ in their peripheral blood. Also, the younger children $<12$ months old had higher antioxidant vitamin values compared with those above 12 months old.

\section{Discussion}

Malaria is a serious parasitic disease and is a major health problem in much of the tropics and subtropics. The justification for this study includes the fact that malaria is endemic in Sokoto and is responsible for mortality and morbidity particularly in the pediatric population, yet no study has been done in Sokoto and indeed the North-West geopolitical zone of Nigeria to investigate the effect of malaria on the antioxidant vitamin levels among preschool children with uncomplicated malaria. In the present study, investigating the antioxidant levels in preschool children with uncomplicated plasmodium malaria, we observed lower antioxidant vitamin concentrations in plasmodium-parasitized children than in the control subjects. The reduction of these antioxidants in the face of malarial infection may predispose the children to free-radical attack. This finding is in agreement with 
Table 2 The antioxidant vitamin status and intensity of malaria parasitemia

\begin{tabular}{|c|c|c|c|c|}
\hline $\begin{array}{l}\text { Intensity of infection or parasite } \\
\text { load }(/ \mu L)\end{array}$ & $\begin{array}{l}\text { Number of } \\
\text { participants }\end{array}$ & $\begin{array}{l}\text { Vitamin A } \\
(\mu \mathrm{g} / \mathrm{dL})\end{array}$ & $\begin{array}{l}\text { Vitamin C } \\
(\mathrm{mg} / \mathrm{dL})\end{array}$ & $\begin{array}{l}\text { Vitamin E } \\
(\mathrm{mg} / \mathrm{dL})\end{array}$ \\
\hline Mild (469.35 \pm 33.34$)$ & 62 & $45.00 \pm 1.51$ & $0.60 \pm 0.03$ & $0.72 \pm 0.03$ \\
\hline Moderate $(2646.0 \pm 146.0)$ & 40 & $26.20 \pm 1.32$ & $0.47 \pm 0.02$ & $0.60 \pm 0.02$ \\
\hline Severe $(10473.00 \pm 207.25)$ & 28 & $14.12 \pm 0.87$ & $0.31 \pm 0.02$ & $0.32 \pm 0.02$ \\
\hline $\begin{array}{l}\text { Mean parasite load of infected subjects } \\
(4529.45 \pm 1237.50)\end{array}$ & 130 & $28.44 \pm 4.13$ & $0.46 \pm 0.04$ & $0.55 \pm 0.05$ \\
\hline Mean parasite load of noninfected controls & 40 & $69.72 \pm 1.71$ & $1.25 \pm 0.04$ & $1.31 \pm 0.04$ \\
\hline
\end{tabular}

previous reports. ${ }^{9-12}$ The low antioxidant vitamin levels observed in this study may be as a result of increased utilization of the host's plasma antioxidants by the malaria parasite to counteract the malarial infection-associated oxidative damages. ${ }^{26}$ Previous reports among children in Papua New Guinea $^{13}$ suggest that vitamin A supplementation could reduce the incidence of plasmodium malaria. Antioxidants have been shown to influence both humoral and cell-mediated immunity as well as counteracting the effect of free-radicals and other products of oxidative stress associated with malarial infection. A significantly lower level of vitamin A was seen in severe malaria-parasitized children compared with the levels of both mild and moderate malarial infections. ${ }^{14,16,17}$ The low concentration of vitamin A seen in malaria-infected children in this study may be attributable to inflammatory response ${ }^{27}$ and redistribution of vitamin A into extra vascular spaces to allow for increased bioavailability to the tissues. ${ }^{28}$

This study revealed that $P$. falciparum-infected children have lower levels of antioxidant vitamins $\mathrm{C}$ and $\mathrm{E}$ compared with control subjects. This finding is consistent with a previous report. ${ }^{16}$ The low concentration of antioxidant vitamins $\mathrm{E}$ and $\mathrm{C}$ may be due to increased utilization of plasma antioxidant or increased destruction during malarial infection. ${ }^{10}$ We observed that the antioxidant levels correlated inversely with the severity of malaria parasitemia and the packed cell volume. This finding is in agreement with the suggestion in a previous report that the higher the level of plasmodium parasitemia, the lower the antioxidant level. ${ }^{29}$

We observed that the predominant plasmodium species responsible for all malarial infections among the children

Table 3 The antioxidant level and malaria parasitemia according to the age of infected subjects

\begin{tabular}{lllll}
\hline $\begin{array}{l}\text { Age } \\
\text { groups } \\
\text { in years }\end{array}$ & $\begin{array}{l}\text { Vitamin A } \\
(\mu \mathrm{g} / \mathrm{dL})\end{array}$ & $\begin{array}{l}\text { Vitamin C } \\
(\mathbf{m g} / \mathbf{d L})\end{array}$ & $\begin{array}{l}\text { Vitamin E } \\
(\mathbf{m g} / \mathbf{d L})\end{array}$ & $\begin{array}{l}\text { Malaria } \\
\text { parasite }(/ \mu L)\end{array}$ \\
\hline$<\mathrm{I}$ & $37.40 \pm 2.20$ & $0.57 \pm 0.04$ & $0.67 \pm 0.04$ & $1589.2 \pm 421.47$ \\
$\mathrm{I}-5$ & $30.84 \pm 4.53$ & $0.48 \pm 0.04$ & $0.57 \pm 0.04$ & $3979.0 \pm 1173.4$ \\
Mean & $34.12 \pm 1.82$ & $0.53 \pm 0.04$ & $0.62 \pm 0.03$ & $2784.1 \pm 1148.2$ \\
\hline
\end{tabular}

studied was $P$. falciparum. This finding is consistent with previous reports in Nigeria which found $P$. falciparum as the predominant species responsible for malarial infection in Nigeria. ${ }^{10,11,30,31}$ Mapping the global distribution of malaria motivated by a need to define populations at risk for appropriate resource allocation, and to provide a robust framework for evaluating its global economic impact, has shown that malarial infection particularly caused by $P$. falciparum has been geographically restricted and remains entrenched in poor areas of the world, particularly in sub-Saharan Africa. ${ }^{32}$

Our study has shown that the antioxidant levels in plasmodium-parasitized children in the North-West of Nigeria are low and that the more severe the malarial infection the lower the antioxidant level and the packed cell volume. There are several daunting challenges associated with effective management of malaria among pediatric populations in developing countries: development of drugresistant strains, late diagnosis, poor mosquito-infested environments, lack of access to health care services, high incidence of self-medication, and patronage of quack chemists and traditional healers for the treatment of malaria. One key strategic intervention is the provision of early diagnosis and prompt effective treatment. A major setback in most settings in sub-Saharan Africa has been the development of drug resistance to commonly used antimalarials. Resistance of $P$. falciparum parasites to antimalarial drugs has fuelled an increase in malaria prevalence and malaria-specific mortality, particularly among children during the past decade in subSaharan Africa. Promising efficacy results from field trials of artemisinin combination therapies are a source of optimism, and numerous African countries have changed their first-line malaria drug policy to artemisinin combination therapies to counter high levels of resistance. ${ }^{33}$ There is also the need to routinely place malaria-parasitized children, particularly those in the North-West of Nigeria, on antioxidants to manage the micronutrient deficiencies seen in these children. There is also the need for the promotion of insecticide-treated bed nets, intermittent preventive treatment, and effective case management of malarial illness among children. 


\section{Limitations of study}

The limitations of this study include the fact that we did not control for other factors that may be confounders that may affect the association between malaria parasitemia and low antioxidant vitamin levels among the preschool children studied. Also we did not include other antioxidant vitamins, particularly ascorbic acid, selenium, zinc, copper, and magnesium. We hope to study these antioxidant vitamins in a subsequent follow-up study.

\section{Disclosure}

The authors report no conflicts of interest in this work.

\section{References}

1. World Health Organization. World Malaria Report. Geneva: World Health Organization; 2010. Available at http://www.who.int/malaria/ world_malaria_report_2010/en/. Accessed June 20, 2013.

2. Snow RW, Korenromp EL, Gouws E. Pediatric mortality in Africa: plasmodium falciparum malaria as a cause or risk? Am J Trop Med Hyg. 2004;71(Suppl 2):16-24.

3. Umar RA, Jiya NM, Ladan MJ, Abubakar MK, Hassan SW, Nata'ala U. Low prevalence of anaemia in a cohort of pre-school children with acute uncomplicated falciparum malaria in Nigeria. Trends Med Res. 2007;2(2):95-101.

4. Greenwood B, Mutabingwa T. Malaria in 2002. Nature. 2002;415: $670-672$.

5. Krogstad DJ. Malaria as a re-emerging disease. Epidemiol Rev. 1996;18:77-79.

6. Olanrewaju WI, Johnson AWBR. Chloroquine-resistant Plasmodium falciparum malaria in Ilorin, Nigeria: prevalence and risk factors for treatment failure. Afr J Med Sci. 2001;30:165-169.

7. Isezuo SA, Kuranga S, Singh S, Crosdale U, Adeojo PI, Abdul-Rasaq SA. Malaria, an opportunity for early diagnosis of systemic hypertension in malaria endemic communities. Sahel Med J. 2002;5:88-91.

8. Black RE. Therapeutic and preventive effect of zinc on serious childhood infectious disease in developing countries. Am J Clin Nutr. 1998;68:476-479.

9. Ekeannyawu PC, Achuka, N, Akpoilih B. Serum level of antioxidant vitamins (Vitamin A, C and E) in Plasmodium falciparum malaria infected children in Owerri, Eastern Nigeria. Biokemistri. 2009;21(2): $53-58$.

10. Nmorsi OPG, Ukwandu NCD, Egwunyenga AO. Antioxidant status of Nigerian children with Plasmodium falciparum malaria. Afr J Microbiol Res. 2007:061-064.

11. Akpotuzor JO, Udoh AE, Etukudo MH. Total antioxidant status vitamin $\mathrm{A}, \mathrm{C}$ and $\beta$-carotene levels of children with $\mathrm{P}$. falciparum in University of Calabar Teaching Hospital (UCTH), Calabar. Pakistan J Nat. 2007;615:485-489.

12. Metzger A, Gelasius M, Schankar A, Ndeezi G, Melikiang G, Semba R. Antioxidant status and acute malaria in children in Kampala, Uganda. Am J Trop Med Hyg. 2001;65:15-19.

13. Hussey DC, Clement CS. Clinical problems in measles case management. Ann Trop Paediatr. 1996;16:307-317.

Journal of Multidisciplinary Healthcare

\section{Publish your work in this journal}

The Journal of Multidisciplinary Healthcare is an international, peerreviewed open-access journal that aims to represent and publish research in healthcare areas delivered by practitioners of different disciplines. This includes studies and reviews conducted by multidisciplinary teams as well as research which evaluates the results or conduct of such teams or
14. Semba RD. The role of vitamin $A$ and related retinoids in immune function. Nutr Rev. 1998;56:38-48.

15. Winklehofor-Roob BM, Ellemunter H, Fruhwirth M, Schlege-Haueter SE, Kloschsoroi G, Van't MA. Plasma vitamin C concentration in patients with cystic fibrosis; evidence of associations with lung inflammation. Am J Clin Nutr. 1997;65:1858-1866.

16. Das BS, Thurnham DI, Das DB. Plasma alpha-tocopherol, retinol and caroteniods in children with falciparum malaria. Am J Clin Nutr. 1996;64:94-100.

17. Kremsner PG, Greve B, Lell B, Luckner D, Schmid D. The influence of zinc supplementation on morbidity due to Plasmodium falciparum: a randomized trial in preschool children in Papua New Guinea. Am J Trop Med Hyg. 2000;62(6):663-669.

18. Adelekan DA, Adeodu OO, Thurnham DI. Comparative effect of malaria and mal-nutrition on plasma antioxidant vitamins in children. Ann F Trop Paediat. 1997; 17:223-227.

19. NPC (National Population Commission). National Census Figures, Abuja, Nigeria, 2007.

20. Molyneaux L, Gramiccia GG. Parasitology. In: Research on the Epidemiology and Control of Malaria in the Sudan Savannah of West Africa. Geneva: WHO; 1980:311.

21. Umar RA, Hassan SW. The relationship between the levels of parasitaemia and anaemia in children with malaria. Sahel Med J. 2002;5:58-62.

22. Breman JG, Alilio MS, White NJ, editors. Defining and Defeating the Intolerable Burden of Malaria III: Progress and Perspectives: Supplement to Volume 77(6) of Am JTrop Med Hyg. Northbrook,IL, USA. Available at http://www.ncbi.nlm.nih.gov/books/NBK1695/. Accessed June 20, 2013.

23. Bassey OA, Lowry OH, Brock MJ, Lopez JA. Determination of vitamin A J Biol Chem. 1946;166:177-178.

24. Roe E, Kuether N. Missing serum vitamin C estimation. In: Varley H, Gowenlock AH. Practical Clinical Biochemistry. Amsterdam: Elsevier; 1943:254-256.

25. Neild HF, Person C. Determination of vitamin E (total tocopherols) in serum. Clin Chem. 1967;10(12):1078-1086.

26. Louw JA, Werbeck A, Louw ME, Koze TJ, Cooper R, Labadarios D. Blood vitamin concentrations during the acute-phase response. Crit Care Med. 1992;20:934-941.

27. Thurnham DI. Antioxidant and proxidants in malnourished populations. Proc Nutr Soc. 1996;49:173-185.

28. Akpotuzor, JO, Udoh AE, Etukudo MH. Total antioxidant status, vitamin $\mathrm{A}, \mathrm{C}$ and $\beta$ carotene levels of children with $\mathrm{P}$. falciparum infection in University of Calabar Teaching Hospital (UCTH), Calabar. Pak J Nutr. 2007;6:485-489.

29. Ugwuja EI, Nwosu KO, Ugwu NC, Okonji M. Serum zinc and copper levels in malnourished pre-school age children in Jos, North Central Nigeria. Pak J Nutri. 2007;6(4):349-354.

30. Erhabor O, Adias TC, Hart ML. Effects of falciparum malaria on the indices of anaemia among pregnant women in the Niger Delta of Nigeria. J Clin Med Res. 2010;2(3):035-041.

31. Erhabor O, Jeremiah ZA, Adias TC, Hart ML. Thrombocytopenia in plasmodium parasitized pregnant women in the Niger Delta of Nigeria. Pathol Lab Med Int. 2010;2:1-5.

32. Snow RW, Guerra CA, Noor AM, Myint HY, Hay SI. The global distribution of clinical episodes of Plasmodium falciparum malaria. Nature. 2005;434:214-217.

33. Njuguna J, Qader SS. Challenges associated with the scaling up of artemisinin combination therapy in sub-Saharan Africa. A review article. Libyan J Med. 2008;3(1):42-48.

Dovepress

healthcare processes in general. The journal covers a wide range of areas and welcomes submission from practitioners at all levels, from all over the world. The manuscript management system is completely online and includes a very quick and fair peer-review system. Visit http://www.dovepress.com/testimonials.php to read real quotes from published authors. 